\title{
Sciendo
}

ACTA UNIVERSITATIS CIBINIENSIS - TECHNICAL SERIES

Vol. 712019

\section{APPLICATION OF E-LEARNING IN ACADEMIC EDUCATION ON THE DIRECTION OF SAFETY AND HYGIENE OF WORK - OPPORTUNITIES AND CHALLENGES IN OPINIONS CONDUCTING CLASSES AND STUDENTS}

\author{
Mariusz Sroka \\ Czestochowa University of Technology, J.H.Dabrowskiego 69, Czestochowa 42-201, Poland
}

\begin{abstract}
The study defines the concept of e-larning and presents the requirements for conducting an effective course to achieve the assumed learning outcomes. As an element of the introduction to the subject, the advantages and disadvantages of e-learning resulting from the experience over the years of organizations that used or continue to use such forms of teaching are presented. The research part presents the results of research carried out in a deliberately selected group of academic teachers and a group of students. The research results presented and discussed include such aspects as: expectations, advantages, disadvantages, fit, convergence of opinions and proposals for improvement of classes conducted in the e-learning mode in the field of Safety and Health at Work. The study is completed by conclusions and proposals of utilitarian solutions in the field of conducting academic education for selected subjects in a fixed time dimension in the form of e-learning.
\end{abstract}

\section{Introduction}

E-learning is a form of teaching implemented with the help of tools and techniques for Internet communication (e-mail, chat, discussion forum, educational platform, instant messenger, video conference, on-line transmission, interactive form). It is an undeniable fact that this form of teaching can support traditional forms of teaching taking place in a full-time mode. E-learning, as an educational platform, has a number of advantages discussed in detail in numerous scientific publications on the subject. The basic premise for using this form of teaching is the availability of materials for the course participants at any time and place. It ensures efficient interaction of the lecturer-student type and efficient interaction between course participants. It should also be noted that the individual and multimedia nature of the courses enables effective teaching and effective implementation of learning outcomes [1-4].

The main advantages of e-learning are:

- any time and place of learning,

- facilitated communication between course participants,

- better adjustment of the material range to the needs of students,

- greater variety through the use of multimedia and non-verbal presentation of teaching materials,

- learning at your own pace,

- minimizing the fear and shyness that often appear with the traditional form of teaching,

- individualization of supervision of the students of the course,

- independent selection of the preferred format for providing knowledge,

- the possibility of repeated playback of sent materials,

- significant profits in dispersed organizations and high employee turnover,

- discussion forums and other forms of electronic remote communication may initiate and encourage the creation of interest groups and mutual assistance groups,

- profitability of infrastructure investments thanks to the economies of scale,

- saving time resulting from the elimination of commuting for both students and academic teachers.

The main disadvantages of e-learning include:

- lack of personal contact with the teacher,

- the impression of isolation experienced by distance learning students,

- developing materials in the form of e-learning is more time-consuming than developing classic educational materials,

- the possibility of difficulties in handling the e-learning platform [5-8]. 


\section{Research methodology}

Questionnaire surveys were carried out from 18 to 24 February 2019. Respondents were students and academic teachers of the Faculty of Management at the Czestochowa University of Technology. The selection of research groups was deliberate. The dean groups of the students in which the questionnaire was conducted were selected randomly from among the groups that participated in the e-learning course at least once. 212 questionnaires were conducted for this population, of which 206 questionnaires were classified after checking the correctness of the fulfillment, consistency and logic of the answers provided for further analysis. In the group of university teachers who conducted or conduct classes in e-learning mode, $50 \%$ of the population were surveyed. The condition for participation in the research was to agree to anonymously complete the questionnaire. The questionnaire contained 3 single-choice questions and 4 multiple-choice questions.

The test results are summarized in the tables. The tables prepared are based on the dependence (1) illustrating the frequency of giving answers of the type $\mathrm{y}(\mathrm{y}=\mathrm{a}, \mathrm{b}, \ldots)$ under the question $\mathrm{x}(\mathrm{x}=1,2,3, \ldots$, $7,8)$.

wherein:

$$
k_{x, y}=\frac{\sum e_{x, y}}{\sum E_{x}} \cdot 100[\%]
$$

$\sum e_{x, y}$ - the number of $\mathrm{y}(\mathrm{y}=\mathrm{a}, \mathrm{b}, \ldots)$ answers given in question $\mathrm{x}$

$\sum E_{x}$ - the total number of responses to question $\mathrm{x}$.

\section{Presentation of research results}

The first question asked about the most important advantages of e-learning. Both research groups in the vast majority indicate the lack of cumbersome commuting to the university and the possibility of education for working people. In other aspects there is a discrepancy. The test results for this part of the survey are presented in Table 1.

Table 1. The most important advantages of e-learning according to the respondents' opinions

\begin{tabular}{|l|c|c|}
\hline \multirow{2}{*}{ Advantages of e-learning } & \multicolumn{2}{|c|}{$\begin{array}{c}\text { Answers } \\
\text { [\%] }\end{array}$} \\
\cline { 2 - 3 } & Students & $\begin{array}{c}\text { Teacher } \\
\text { s }\end{array}$ \\
\hline $\begin{array}{l}\text { Opportunity to acquire knowledge at any } \\
\text { time and place }\end{array}$ & 75 & 20 \\
\hline Individualized pace of learning & 80 & 35 \\
\hline $\begin{array}{l}\text { No uncomfortable commuting to the } \\
\text { university }\end{array}$ & 82 & 80 \\
\hline Lowering the cost of education & 30 & 15 \\
\hline Alignment of educational opportunities & 25 & 10 \\
\hline Individualization of education programs & 40 & 30 \\
\hline $\begin{array}{l}\text { Possibility of education for working } \\
\text { people }\end{array}$ & 60 & 40 \\
\hline Possibility of education at any age & 45 & 35 \\
\hline $\begin{array}{l}\text { Possibility of education for people with a } \\
\text { family }\end{array}$ & 30 & 42 \\
\hline
\end{tabular}

The next question was about the disadvantages of e-learning. The convergence of indications for this question occurs for the answer: "limited offer of courses" and the necessity of having computer equipment. The remaining answers in individual research groups are divergent. The test results for this question are presented in Table 2. 
Table 2. The most important disadvantages of e-learning according to the respondents' opinions

\begin{tabular}{|l|c|c|}
\hline \multirow{2}{*}{ Disadvantages of e-learning } & \multicolumn{2}{|c|}{ Answers [\%] } \\
\cline { 2 - 3 } & Students & $\begin{array}{c}\text { Teacher } \\
\text { S }\end{array}$ \\
\hline The coercion of internal mobilization & 82 & 10 \\
\hline The necessity of having computer equipment & 10 & 15 \\
\hline Too many different e-learning platforms & 15 & 44 \\
\hline Limited offer of courses & 85 & 68 \\
\hline No personal contact with the teacher & 25 & 33 \\
\hline $\begin{array}{l}\text { No personal contact with other participants of } \\
\text { the course }\end{array}$ & 72 & 8 \\
\hline $\begin{array}{l}\text { Increased spending on telecommunications } \\
\text { services }\end{array}$ & 5 & 11 \\
\hline $\begin{array}{l}\text { Difficulties in determining students' progress } \\
\text { in learning }\end{array}$ & 54 & 71 \\
\hline Complicated use of the educational platform & 13 & 52 \\
\hline
\end{tabular}

The next question was about preferred forms and e-learning tools. We can observe here the convergence regarding opinions on the transmission of on-line lectures, didactic materials and video conferences. In the remaining responses, the respondents expressed diametrically opposed opinions. The test results for this part of the survey are presented in Table 3.

The next question was about determining the value of education for knowledge acquired during elearning courses in the opinion of the respondents. Both research groups indicate a good or sufficient value. Respondents in a small percentage indicate a value insufficient or greater than knowledge and education obtained in a traditional way. Research results for this part of the survey are presented in Table 4.

Table 3. Preferred forms and tools of e-learning indicated by the respondents

\begin{tabular}{|l|c|c|}
\hline \multirow{2}{*}{ Forms and tools of e-learning } & \multicolumn{2}{|c|}{ Answers [\%] } \\
\cline { 2 - 3 } & $\begin{array}{c}\text { Student } \\
\text { s }\end{array}$ & Teachers \\
\hline $\begin{array}{l}\text { Teaching materials on the e-learning } \\
\text { platform }\end{array}$ & 80 & 85 \\
\hline Didactic materials sent to e-mail & 75 & 21 \\
\hline Transmission of lectures on-line & 5 & 4 \\
\hline Videoconferencing & 5 & 2 \\
\hline Discussion forums and blogs & 12 & 5 \\
\hline Interactive exercises - quizzes and tests & 24 & 87 \\
\hline Virtual laboratories & 5 & 77 \\
\hline Exams and credits in electronic form & 90 & 16 \\
\hline
\end{tabular}

Table 4. The value of education and knowledge acquired during e-learning courses in the opinion of the surveyed

\begin{tabular}{|l|c|c|}
\hline \multirow{2}{*}{ Rating } & \multicolumn{2}{|c|}{ Answers [\%] } \\
\cline { 2 - 3 } & $\begin{array}{c}\text { Student } \\
\text { s }\end{array}$ & $\begin{array}{c}\text { Teache } \\
\text { rs }\end{array}$ \\
\hline Insufficient & 0 & 2 \\
\hline
\end{tabular}




\begin{tabular}{|l|c|c|}
\hline Sufficient & 10 & 58 \\
\hline Good & 67 & 30 \\
\hline $\begin{array}{l}\text { Comparable to knowledge and education obtained in a } \\
\text { traditional way }\end{array}$ & 18 & 10 \\
\hline $\begin{array}{l}\text { Greater than knowledge and education obtained in a } \\
\text { traditional way }\end{array}$ & 5 & 0 \\
\hline
\end{tabular}

The next question was about preferred forms and e-learning tools for further learning in the group of students and forms of conducting classes among academic teachers. Convergence of indications $(2 \%$ and $0 \%$ respectively) occurs only for answers about conducting education in $100 \%$ in e-learning mode. Other responses in this respect are diametrically opposed. The test results for this part of the survey are summarized in Table 5.

Table 5. Preferred form of further education / conducting classes

\begin{tabular}{|l|c|c|}
\hline \multirow{2}{*}{$\begin{array}{c}\text { Preferred form of further education / } \\
\text { conducting classes }\end{array}$} & \multicolumn{2}{|c|}{ Answers [\%] } \\
\cline { 2 - 3 } & Students & $\begin{array}{c}\text { Teacher } \\
\text { s }\end{array}$ \\
\hline Traditional method (100\%) & 3 & 30 \\
\hline E-learning mode (100\%) & 2 & 0 \\
\hline Mixed mode (traditional 50\% / e-learning 50\%) & 50 & 18 \\
\hline $\begin{array}{c}\text { Mixed mode - the predominance of the } \\
\text { traditional form }\end{array}$ & 10 & 52 \\
\hline $\begin{array}{c}\text { Mixed mode - the advantage of the e-learning } \\
\text { form }\end{array}$ & 35 & 0 \\
\hline
\end{tabular}

In the next question, the respondents were to define the demand for education in the form of e-learning. In this part there is a large convergence of responses for individual groups of respondents. They indicated in the vast majority on the average demand for this form of education. None of the surveyed groups indicated no demand. Research results for this part of the survey are presented in Table 6.

Table 6. Demand for education in the form of e-learning

\begin{tabular}{|l|c|c|}
\hline \multirow{2}{*}{ Request } & \multicolumn{2}{|c|}{ Answers [\%] } \\
\cline { 2 - 3 } & Students & Teachers \\
\hline Big & 40 & 30 \\
\hline Medium & 55 & 60 \\
\hline Small & 5 & 10 \\
\hline $\begin{array}{l}\text { None (no } \\
\text { request) }\end{array}$ & 0 & 0 \\
\hline
\end{tabular}

The last question was about actions to improve courses conducted in e-learning mode. In this question there is a large discrepancy among the indications for individual groups of respondents. Both studied groups perceive the improvement of courses through different activities. The test results for this part of the survey are presented in Table 7.

Table 7. Improvement of courses conducted in e-learning mode

\begin{tabular}{|l|c|c|}
\hline \multirow{2}{*}{ Improving action } & \multicolumn{2}{|c|}{ Answers [\%] } \\
\cline { 2 - 3 } & $\begin{array}{c}\text { Student } \\
\text { s }\end{array}$ & $\begin{array}{c}\text { Teache } \\
\text { rs }\end{array}$ \\
\hline $\begin{array}{l}\text { Developing self-assessment tools for } \\
\text { progress }\end{array}$ & 46 & 24 \\
\hline
\end{tabular}




\begin{tabular}{|l|c|c|}
\hline Unification of e-learning platforms & 11 & 65 \\
\hline Extension of the course offer & 68 & 10 \\
\hline $\begin{array}{l}\text { Training on the use of the e-learning } \\
\text { platform }\end{array}$ & 20 & 70 \\
\hline
\end{tabular}

\section{Summary}

According to the respondents, the most important advantage of e-learning (which is indicated by both students and academic teachers) is the lack of cumbersome commuting to the university and the possibility of education for people who work or have a family. The opportunity to acquire knowledge at any time and place and the individualized pace of learning is more important for students than for teachers.

Students indicate the compulsion of internal mobilization and the limited offer of courses as the main disadvantages of e-learning. A big drawback from the point of view of students is the lack of personal contact with other participants of the course and difficulties in determining progress in learning. On the other hand, teachers as the main drawbacks indicate difficulties in determining progress in learning, limited offer of courses and complicated use of the e-learning platform. Convergence of opinions of students and teachers concerns the form and tools of e-learning - both groups indicate placing materials on the platform as the most appropriate form. On the other hand, they have a diametrically opposed opinion regarding virtual laboratories and exams as well as electronic credits. Preferences in this area indicate different expectations of both groups.

The assessment of the value of education and knowledge acquired during e-learning courses is also divergent in both groups surveyed. As good, it is mainly determined by students, while teachers judge it as sufficient.

As for the preferred form of further education, students would most preferably see the mixed mode in a half-and-a-half ratio. However, academic teachers prefer the traditional form of e-learning advantage. Both groups of respondents consider the level of demand for education in the form of e-learning to be medium.

As we can see, expectations regarding the e-learning system are divergent in both groups of respondents, with the exception of full compliance in relation to the elimination of onerous commuting to the university. Therefore, it is important to find a solution that makes e-learning courses more attractive and simplify the way of creating and placing teaching materials on the platform; as we can see, students are rather positive about this form of education, while teachers find it difficult to prepare materials for the course a long time or read a lot of student e-mails - both sides find it useful to increase student selfesteem, which would allow students to better control the learning outcomes and teachers it would simplify the work and reduce the time needed to verify the absorption of basic content.

In the light of the studies quoted, the activities aimed at improving e-learning courses in the studied groups have different priorities: as the most important students indicate the extension of course offerings and development of self-assessment tools in progress, while teachers see the harmonization of e-learning platforms and organized training in the field of e-learning platform support.

It seems that the research carried out unequivocally defines the preferences of the studied groups regarding teaching in the form of e-learning and indicate specific activities that should be introduced by decision-makers at universities, so as to improve the attractiveness of e-learning courses.

\section{References}

1. D. Jelonek, A. Dunay, B. Csaba Illes, PJMS 16, 122-132 (2017)

2. E. Wysłocka, PJMS 11, 188-189 (2015)

3. B. Klímová, JMS, 42, 194 (2018)

4. H. Al-Samarraie, B. Kim Teng, A.I. Alzahrani, N. Alalwan, JSHE,43, 2003-2019, (2018)

5. S. L. Murphy, E.M. Samuels, C. Byks-Jazayeri, E. Cha, JCTS, 2, 55, (2018)

6. E.Vezzetti, M. Violante, CAEE, (2013)

7. M. Firat, H. Kılınç, T Volkan Yüzer, JCAL, 34, 63-70, (2018)

8. S. Ponomareva, E. Ugnich, SHS Web Conference, 50, 4, (2018) 